International Journal of Public Health Excellence (IJPHE)

Vol. 1, No. 1, January 2022, pp. 1 5

Journal homepage: https://ejournal.ipinternasional.com/index.php/ijphe/

ISSN: 2809-9826, DOI: https://doi.org/10.55299/ijphe.v1i1.2

\title{
The Relationship between Physical Conditions of the House and the Incidence of Tuberculosis
}

\author{
Rahmah Juliani Siregar ${ }^{1}$, Susi Febriani Yusuf ${ }^{2}$, Devrich Fernaldy ${ }^{3}$ \\ ${ }^{1}$ Public Health Study Program, STIKes Darmais Padangsidimpuan, Indonesia \\ ${ }^{2}$ Public Health Study Program, STIKes Darmais Padangsidimpuan, Indonesia \\ ${ }^{3}$ Public Health Study Program, STIKes Darmais Padangsidimpuan, Indonesia
}

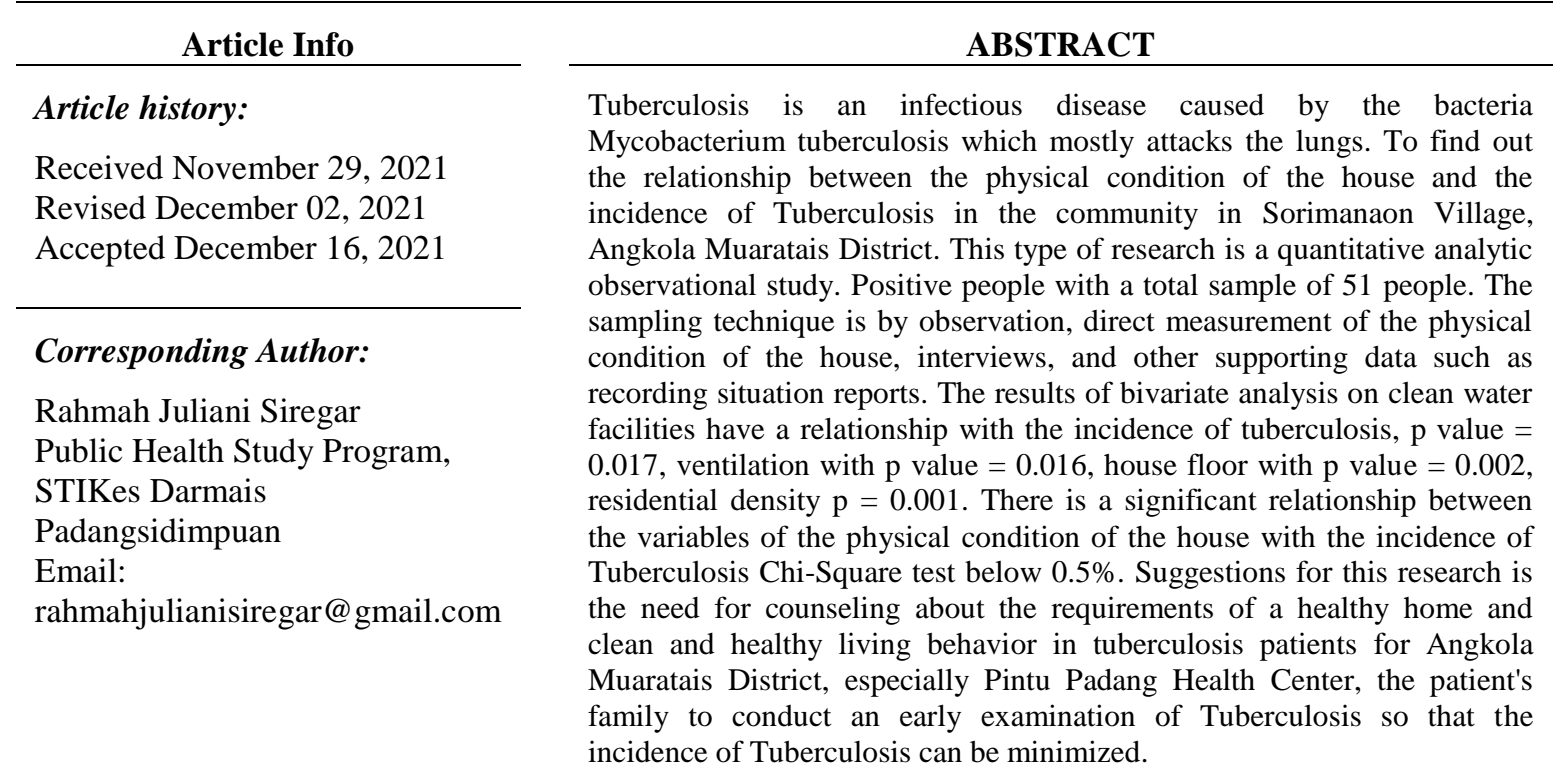

Keywords:

Tuberculosis, Characteristics of Respondents, Physical Condition of the House

This article is licensed under a Creative Commons AttributionShareAlike 4.0 International License..

\section{INTRODUCTION}

According to WHO in the 2017 Global Report on Tuberculosis, 10.4 million cases of Tuberculosis have occurred globally. Tuberculosis is the 10th leading cause of death in the world and global tuberculosis deaths are estimated at 1.3 million patients. Based on the WHO Global Tuberculosis Report [26], the incidence rate of Tuberculosis in Indonesia is 391 per 100,000 population and the death rate is 42 per 100,000 population, while according to modeling based on data from the 2016-2017 Tuberculosis prevalence survey, the prevalence rate in 2018 was 619 per 100,000 population. 2016 was 628 per 100,000 population.

In 2019, based on Indonesia's health profile, North Sumatra Province occupies the 5th position, being one of the provinces that has the highest cases in Indonesia with 20,429 cases. Based on the 2018 District/City Health Profile, the average treatment success rate at the provincial level reached $92.19 \%$, with a breakdown of the recovery percentage of $85.52 \%$, but this has increased by $2.58 \%$ compared to 2017 (89.61\%). The success rate in 2018 has been able to exceed the national target of 85\%. Of the 33 regencies/cities, there are 3 regencies/cities that have not been able to achieve a success rate of $85 \%$, including Medan and with 3,139 cases (21.50\%), Mandailing Natal Regency 187 (9.65\%), and South Tapanuli Regency 382 (13.66). \%) [6]. This figure shows that Tuberculosis in North Sumatra, especially in the South Tapanuli Regency area, still has a high number of Tuberculosis cases.

Regional data of Angkola Muaratais Sub-district which is located in the Working Area of Pintu Padang Health Center, South Tapanuli Regency with a working area of 14 sub-districts and villages, namely: Bintuju Village, Huta Tonga Village, Sipangko Village, Holbung, Promise Mauli, Muara Tais I, Muara Tais II , Muara Tais III, Pargumbangan, Pangaribuan, Sorimanaon, Muara Purba Nauli, Huta Tengger, Pasir Matogu, the Int Jou of PHE 
number of cases of Tuberculosis sufferers in 2018 was 233 and increased in 2019 to 353 people, increased again in 2020 increased to 660 people and in From January to March 2021, the number of cases of tuberculosis sufferers was 103 people. The initial survey shows that Tuberculosis is among the 10 highest diseases in South Tapanuli Regency. The majority of patients with pulmonary TB at the Pintu Padang Health Center are 70 men, while 37 women are. In addition, pulmonary TB patients at this health center mostly occur in the productive age (15-69 years) as many as 57 people, while the age of 50 years is 40 people, and the age of children is 17 people [20]

The physical condition of the houses of the people of South Tapanuli Regency was found to be not meeting the requirements of a healthy home and there was still a lack of awareness of the community's actions towards Tuberculosis so that Tuberculosis sufferers in the area were included in the high category. In 2020, in Angkola Muaratais District, 6,111 houses were found that did not meet the health requirements of the 14,869 total houses in the area [21].

Based on an initial survey conducted by researchers on April 10, 2021 on 8 TB patients in the working area of the Pintu Padang Health Center, the results of a preliminary study found that five people with soil and damp house floor conditions, one person did not have ventilation at home. . Three of them said that clean water was not available to meet family needs because the number in one family reached 10 people with low economic reasons, they could only meet their daily needs.

\section{METHOD}

The type of research used is an observational quantitative analytic study. The aim is to determine the relationship between the physical condition of the house (clean water facilities, ventilation, floors, and housing density) with the incidence of tuberculosis in the community in Sorimanaon Village, Angkola Muaratais District, South Tapanuli Regency in 2021, where measurements or observations are carried out at the same time on independent variable data. and dependent (once) in one measurement using a questionnaire measuring instrument [7]. To see a picture of each variable consisting of general data covering the characteristics of the respondent, the physical condition of the respondent's house, and the incidence of tuberculosis. These data are displayed in the form of a frequency distribution. To identify the relationship of the independent variables, namely individual characteristics (age, gender, education, and occupation) and the physical condition of the house (clean water facilities, ventilation, floors, and house occupancy density) with the dependent variable the incidence of tuberculosis. The statistical test used is the Chi-Square Test with a degree of confidence of $0.5 \%$ [23]

Table 1. Sample distribution

\begin{tabular}{lcc}
\hline \multicolumn{1}{c}{ Characteristics of Respondents } & F & \% \\
\hline Age & & \\
<15 years old & 8 & 15,7 \\
15-50 years & 36 & 70,6 \\
$>$ 50 years & 7 & 13,7 \\
Gender & 20 & 39,2 \\
Man & 31 & 60,8 \\
Woman & & \\
Education & 3 & 5,9 \\
No school & 17 & 33,3 \\
Elementary School & 8 & 15,7 \\
Graduated from Middle School/Equivalent & 16 & 31,4 \\
High school graduate/equivalent & 7 & 13,7 \\
Graduated D3/PT & & \\
Work & 4 & 7,8 \\
Civil Servants/Retirees & 1 & 2,0 \\
Private Supervisor & 14 & 27,5 \\
entrepreneur & 10 & 19,6 \\
Student/Student & 6 & 11,8 \\
Farmer & 16 & 31.4 \\
IRT & & \\
Income & 26 & 51.0 \\
Low (<UMR Rp2,903,042) & 25 & 49.0 \\
\hline High (>/UMR Rp 2,903,042) & $\mathbf{5 1}$ & $\mathbf{1 0 0 . 0}$ \\
\hline Total & & \\
\hline
\end{tabular}

\section{RESULTS AND DISCUSSION}

The supporting facilities for health services at the Pintu Padang Health Center are as follows: 1) Individual health business (UKP) includes: registration, outpatient care, emergency department, pharmacy, $\mathrm{MCH}$ and family planning, childbirth and child health, dental and oral health, nutrition, laboratory. 2) Community health efforts (UKM Development) include: mental health, elderly health, community dental health, sensory 
health, pulmonary TB, PTM. 3) Essential UKM and public health nursing include: SP2TP, immunization, P2 ARI, P2 TB, P2 Leprosy, P2 Rabies, P2 Diarrhea, P2 Measles, P2 Typoid, P2 Malaria, surveillance, nutrition, maternal health, child health, family planning, health reproduction, early detection and IMCI, health promotion, PHBS, PSM, UKS. 4) The puskesmas service network and the pasyankes network include: mobile health centers, pasyankes facilities, sub-health centers, and village midwives.

\subsection{Result}

It was conducted to identify the relationship between the independent variables, namely the physical condition of the respondent's house (clean water facilities, ventilation, floors, and housing density) and the dependent variable on the incidence of tuberculosis in the community in Angkola Muaratais District, South Tapanuli Regency with chi-square test at a 95\% confidence level.

Table 2. Relationship between physical conditions at home with tuberculosis.

\begin{tabular}{|c|c|c|c|c|c|c|c|}
\hline \multirow{3}{*}{ Variable } & \multicolumn{4}{|c|}{ Tuberculosis Disease } & \multirow{2}{*}{\multicolumn{2}{|c|}{ Amount }} & \multirow{3}{*}{ P value } \\
\hline & \multicolumn{2}{|c|}{$\begin{array}{c}\text { No } \\
\text { Tuberculosis } \\
\text { Patients } \\
\end{array}$} & \multicolumn{2}{|c|}{ Tuberculosis Patients } & & & \\
\hline & $\mathbf{F}$ & $\%$ & $\mathbf{F}$ & $\%$ & $\mathbf{F}$ & $\%$ & \\
\hline \multicolumn{8}{|c|}{ Clean Water Facilities } \\
\hline Not eligible & 10 & 19,6 & 19 & 37,3 & 29 & 56,9 & 0,017 \\
\hline Qualify & 15 & 29,4 & 7 & 13,7 & 22 & 43,1 & \\
\hline \multicolumn{8}{|l|}{ Ventilation } \\
\hline No ventilation & 11 & 21,6 & 20 & 39,2 & 27 & 52,9 & 0,016 \\
\hline There is ventilation & 14 & 27,5 & 6 & 11,8 & 24 & 47,1 & \\
\hline \multicolumn{8}{|l|}{ House floor } \\
\hline Not waterproof & 6 & 11,8 & 21 & 41,2 & 27 & 52,9 & 0,002 \\
\hline Water proof & 19 & 37,3 & 5 & 9,8 & 24 & 47,1 & \\
\hline \multicolumn{8}{|l|}{ Occupancy density } \\
\hline$<8 \mathrm{~m} 22$ persons & 8 & 15,7 & 20 & 39,2 & 28 & 54,9 & 0,001 \\
\hline $8 \mathrm{~m} 2<2$ people & 17 & 33,3 & 6 & 11,8 & 23 & 45,1 & \\
\hline Total & 25 & 49,0 & 26 & 51,0 & 51 & 100,0 & \\
\hline
\end{tabular}

Based on the results of the bivariate analysis between the variables covering the physical condition of the respondent's house (clean water facilities, ventilation, floors, and housing density) and the incidence of tuberculosis in the community in Sorimanaon Village, Angkola Muaratais District, South Tapanuli Regency, it was found that:

First, based on the results of the cross tabulation between clean water facilities and the incidence of tuberculosis, it shows that of the 29 respondents who did not meet the requirements, there were 10 people (19.6\%) who did not have tuberculosis and 19 people $(37.3 \%)$ who had tuberculosis. Meanwhile, of the 22 respondents who did not meet the requirements, there were 15 people $(29.4 \%)$ who did not have tuberculosis and 7 people $(13.7 \%)$ who had tuberculosis. The results of the Chi Square analysis show that the p value is 0.017 (p $<0.05)$ meaning that $\mathrm{Ha}$ is accepted and $\mathrm{HO}$ is rejected. These results prove that there is a significant relationship between clean water facilities and the incidence of tuberculosis in the community in Sorimanaon Village, Angkola Muaratais District, South Tapanuli Regency 2021.

Second, based on the results of the cross tabulation between ventilation and the incidence of tuberculosis, it shows that of the 27 respondents who did not have ventilation, there were 11 people $(21.6 \%)$ who did not have tuberculosis and 20 people (39.2\%) who had tuberculosis. Meanwhile, of the 24 respondents who had ventilation, there were 14 people $(27.5 \%)$ who did not have tuberculosis and 6 people $(11.8 \%)$ who had tuberculosis. The results of the Chi Square analysis show that the $\mathrm{p}$ value is $0.016(\mathrm{p}<0.05)$ meaning that Ha is accepted and $\mathrm{HO}$ is rejected. These results prove that there is a significant relationship between ventilation and the incidence of tuberculosis in the community in Sorimanaon Village, Angkola Muaratais District, South Tapanuli Regency 2021.

Third, based on the results of the cross tabulation between the floor of the house and the incidence of tuberculosis, it showed that of the 27 respondents who were not waterproof, there were $6(11.8 \%)$ who did not suffer from tuberculosis and 21 people $(41.2 \%)$ who had tuberculosis. Meanwhile, of the 24 respondents who were waterproof, there were 19 people $(37.3 \%)$ who did not have tuberculosis and 5 people $(9.8 \%)$ who had tuberculosis. The results of the Chi Square analysis show that the p value is $0.002(\mathrm{p}<0.05)$ meaning Ha is accepted and $\mathrm{HO}$ is rejected. These results prove that there is a significant relationship between the floor of the house and the incidence of tuberculosis in the community in Sorimanaon Village, Angkola Muaratais District, South Tapanuli Regency 2021. 
Fourth, based on the results of cross tabulation between residential density and the incidence of tuberculosis, it shows that of the 28 respondents who were $<8 \mathrm{~m} 22$ people, there were $8(15.7 \%)$ who did not have tuberculosis and 20 people $(39.2 \%)$ who had tuberculosis. Meanwhile, from 23 respondents with $8 \mathrm{~m} 2<2$ people, there were 17 people (33.3\%) who did not suffer from tuberculosis and 6 people $(11.8 \%)$ who had tuberculosis. The results of Chi Square analysis show that the p value is $0.001(\mathrm{p}<0.05)$ meaning Ha is accepted and $\mathrm{HO}$ is rejected. These results prove that there is a significant relationship between residential density and the incidence of tuberculosis in the community in Sorimanaon Village, Angkola Muaratais District, South Tapanuli Regency 2021 [4].

\subsection{Discussion}

The results of the analysis of the relationship between the physical conditions of the house include several aspects, namely: clean water facilities for house ventilation, house floors, house occupancy density can be described as follows:

\subsubsection{Clean Water Facilities}

This is in accordance with the results [2], that there is a significant relationship between clean water facilities and Tuberculosis, this indicates that there are factors that cause the non-compliance of clean water facilities in the respondent's house affected by tuberculosis. This study is in accordance with research conducted [8], which revealed that there was a significant relationship between clean water facilities and the incidence of tuberculosis. Clean water requirements are regulated by the Regulation of the Minister of Health of the Republic of Indonesia Number 32 of 2017 concerning Environmental Health Quality Standards and Water Health Requirements. Wells are the main source of clean water supplies for people living in rural and urban areas [1]. One of the types of wells used to obtain groundwater is dug wells. In order for dug well water to meet health requirements, it must be protected against the dangers of pollution. The effort that can be done is to pay attention to the construction of wells, which must meet the requirements.

\subsubsection{Ventilation}

Air quality in the house is related to ventilation problems and the activities of the occupants in it. The increasing number of residents in urban settlements causes building density and it is difficult to make ventilation and there are even houses that do not have windows, no vents and no sunlight enters, the air in the house feels stuffy. The journey of Tuberculosis germs after being coughed up will be inhaled by the people around them to the lungs, so that good ventilation will ensure air exchange, so that the droplet concentration can be reduced. The concentration of droplets per volume of air and the length of time inhaling the air allows a person to be infected with Tuberculosis germs [10-12]

\subsubsection{Floor}

Floors that do not meet the requirements can be used as a place to live and breed bacteria, especially Mycobacterium Tuberculosis bacteria. Making the air in the room humid, in the summer the floor becomes dry, causing dust that is harmful to the occupants. According to the Decree of the Minister of Health of the Republic of Indonesia No. 829/Menkes/SK/VII/1999 concerning Housing Health Requirements, the floor of the house is not made of materials that can grow and develop pathogenic microorganisms, the floor is waterproof and easy to clean [13-14].

\subsubsection{House Occupancy Density}

The condition of residential density will affect the air quality in the room. Such as increasing levels of $\mathrm{CO} 2$ in the room so that the supply of $\mathrm{O} 2$ needed by residents in the house is reduced. Density of residents will also affect the transmission of tuberculosis through close contact with tuberculosis sufferers with other residents of the house, so that the risk of contracting this disease is even greater.

\section{CONCLUSION}

Based on the results of observations, interviews and statistical tests in research with the incidence of tuberculosis in the community in Angkola Muaratais District, South Tapanuli Regency 2021, conclusions can be drawn: 1) There is a relationship between clean water sources and the incidence of tuberculosis in the community in Angkola Muaratais District, South Tapanuli Regency with a value of p value 0.017(p<0.05). 2) There is a relationship between home ventilation conditions and the incidence of tuberculosis in the community in Angkola Muaratais District, South Tapanuli Regency with a p value of 0.016 ( $p<0.05$ ). 3) There is a relationship between the condition of the floor of the house and the incidence of tuberculosis in the community in Angkola Muaratais District, South Tapanuli Regency with a p value of 0.002 ( $p<0.05)$. 4) There is a relationship between housing density conditions and the incidence of tuberculosis in the community in Angkola Muaratais District, South Tapanuli Regency, with a p value of $0.001(\mathrm{p}<0.05)$.

\section{ACKNOWLEDGEMENTS}


Author thanks Mrs. Susi Febriani Yusuf and Devrich Fernaldy. In most cases, sponsor and financial support.

\section{REFERENCES}

[1] Achmadi, U, Environmentally based disease management, vol. 4, $2^{\text {nd }}$ ed, Jakarta, Indonesia: UI Press, 2015

[2] K.S. Amalia, "The Relationship between the Physical Condition of the House and the Incidence of Pulmonary Tuberculosis in the Work Area of the Ngemplak Boyolali Public Health Center", M.S.Thesis., the Faculty of Health Sciences, Muhammadiyah Univ, Surakarta, Indonesia, 2015

[3] Azwar, A, Introduction to environmental health. Vol. 9, 3rd ed. Jakarta, Indonesia: PT. Rhineka Cipta, 2016

[4] District Health Office. South Tapanuli. [2020]. Kab. South Tapanuli.

[5] North Sumatra Health Office. [2019]. TB Program Annual Report. Medan.

[6] Febriani, T, "The influence of students' perceptions of a smoke-free area and support for its application at the University of North Sumatra". M.A.Thesis, Dept. Public Health. Univ of North Sumatra. Medan, Indonesia, 2014.

[7] Hidayat, A, Quantitative Paradigm Health Research Methods. Vol. 1. $2^{\text {nd }}$ ed, Surabaya, Indonesia: Health Books Publishin, 2014

[8] Kasjono HS, Residential Health. Vol. 2, 3nd ed, Yogyakarta, Indonesia: Gosyen Publishing, 2011

[9] Indonesian Ministry of Health. [2017]. National Guidelines for Tuberculosis Management Medical Services. Jakarta: Ministry of Health RI

[10] Indonesian Ministry of Health. [2018]. National Guidelines for Tuberculosis Control. Jakarta: Ministry of Health RI

[11] Indonesian Ministry of Health. [2018]. Tuberculosis Prevalence Survey 2016-2017. Jakarta: Ministry of Health RI

[12] Indonesian Ministry of Health. [2019]. Indonesia Health Profile Data and Information 2020. Jakarta: Ministry of Health RI

[13] Decree of the Minister of Health of the Republic of Indonesia Number 829 of 1999 concerning Housing Health Requirements

[14] Decree of the Minister of Health of the Republic of Indonesia Number 67 of 2016 concerning Tuberculosis Management.

[15] Lukluk, B., Health psychology. Vol. 5, $3^{\text {rd }}$ ed, Yogyakarta, Indonesia: Scholar Partners, 2018

[16] Naga, S. A complete guide to internal medicine. Vol. 2, $2^{\text {nd }}$ ed, Yogyakarta, Indonesia: PT. Yogyakarta, 2012

[17] Notoatmodjo, S, Health education and behavior. Vol. 8, $6^{\text {th }}$ ed, Jakarta, Indonesia: Rhineka Cipta. 2013

[18] Notoatmodjo, S. Public health science and art. Vol. 4, $5^{\text {th }}$ ed, Jakarta, Indonesia: Rhineka Cipta, 2013

[19] Regulation of the Minister of Health of the Republic of Indonesia Number 416 of 1990 concerning Requirements and Monitoring of Water Quality.

[20] Profile of Pintupadang Health Center. [2021]. TB Program Annual Report. Field Door.

[21] Profile of Angkola Muaratais District [2021]. The Annual Report of a decent house. Angkola Muaratais

[22] Sarwono, S. Adolescent psychology. Vol. 2, $2^{\text {nd }}$ ed, Jakarta, Indonesia: King Grafindo Pustaka, 2014

[23] Soesanto, S., Lubis, A., \& Atmosukarto, K, Relationship of housing conditions with the transmission of ARI and pulmonary tuberculosis: Health Research and Development Media. Vol. 10, $2^{\text {nd }}$ ed, Bandung, Indonesia: Rineka Cipta, 2010

[24] Law of the Republic of Indonesia Number 4 of 1992 concerning Housing and Settlements.

[25] Widoyono, Tropical diseases, epidemiology, transmission, prevention and eradication. Vol. 2, $2^{\text {nd }}$ ed, Jakarta, Indonesia: Erlangga, 2018

[26] WHO "Global Tuberculosis Report 2017," Who int. $\quad 2018$ [Online]. apps.who.int/iris/bitstream/10665/191102/1/9789241565059eng.pdf. [Cited April 4, 2021]

[27] Yuwono, T, "Physical environmental factors of the house related to the incidence of pneumonia in children under five in the working area of the Kawunganten Health Center, Cilacap Regency,” M.S. thesis, Dept Medicine, Diponegoro Univ., Semarang.,Jateng,.2018. 